\title{
ANALISIS TINDAK TUTUR ILOKUSI DALAM DIALOG NASKAH DRAMA PEACE KARYA PUTU WIJAYA DAN RELEVANSINYA DENGAN MATERI AJAR SASTRA DI SEKOLAH MENENGAH ATAS
}

\author{
Maria Puspita Destaningtyas Bening Rasa., Andayani, Chafit Ulya \\ Universitas Sebelas Maret \\ Surel: beningrasa@student.uns.ac.id
}

\begin{abstract}
Abstrak: Penelitian ini bertujuan untuk mendeskripsikan dan menjelaskan (1) bentuk tindak tutur ilokusi dalam dialog naskah drama Peace karya Putu Wijaya; (2) fungsi tindak tutur ilokusi dalam dialog naskah drama Peace karya Putu Wijaya; dan (3) relevansi tindak tutur ilokusi dalam dialog naskah drama Peace karya Putu Wijaya dengan materi ajar sastra di Sekolah Menengah Atas. Penelitian ini merupakan penelitian deskriptif kualitatif dengan jenis pendekatan pragmatik. Sumber data penelitian ini adalah dokumen yang berupa naskah drama Peace karya Putu Wijaya. Teknik pengambilan subjek penelitian ini dilakukan dengan sampel bertujuan (purposive sampling). Pengumpulan data dilakukan dengan teknik analisis dokumen. Uji validitas data yang digunakan adalah teknik triangulasi teori tindak tutur ilokusi Searle dan triangulasi sumber data berupa informan. Analisis data dalam penelitian ini menggunakan analisis data menurut Miles dan Huberman yaitu model mengalir. Hasil penelitian adalah sebagai berikut. Pertama, dari kelima bentuk tindak tutur ilokusi, yang paling dominan muncul pada naskah drama Peace karya Putu Wijaya adalah bentuk ilokusi direktif. Kedua, fungsi tindak tutur ilokusi yang paling dominan muncul pada naskah drama Peace karya Putu Wijaya adalah bentuk ilokusi direktif yang berfungsi meminta dan memerintah. Ketiga, dialog tindak tutur ilokusi dalam naskah drama Peace karya Putu Wijaya dapat dijadikan sebagai rujukan materi ajar sastra di SMA karena memenuhi 3 aspek penting tentang materi ajar yaitu (1) segi bahasa; (2) segi kematangan jiwa; dan (3) segi latar belakang kebudayaan; serta sesuai dengan kurikulum yang berlaku.
\end{abstract}

Kata Kunci: naskah drama, dialog naskah drama, tindak tutur ilokusi, materi ajar, pembelajaran sastra

\section{ANALYSIS OF ILOCUSION IN THE DIALOGUE OF PLAY SCRIPT PEACE BY PUTU WIJAYA AND ITS RELEVANCE WITH LITERATURE LEARNING MATERIALS IN SENIOR HIGH SCHOOL}

\begin{abstract}
This study aims to describe and explain: (1) the form of illocutionary speech acts in Putu Wijaya's Peace drama script dialogue; (2) the function of illocutionary speech acts in Putu Wijaya's Peace drama script dialogue; and (3) the relevance of illocutionary speech acts in Putu Wijaya's Peace drama script dialogue and literature teaching materials in senior high school. This research is a qualitative descriptive research with type of pragmatic approach. Sources of data was a document which is the Putu Wijaya's Peace drama script dialogue. The technique for taking the subject of this research was done by purposive sampling. Data collection was done by document analysis. Theory triangulation is Searle's illocutionary speech acts and data sources triangulation in the form of informants was used for validity test of the data. Data analysis in this study was using data analysis according to Miles and Huberman with the flow model. The results of the study are as follows. First, from five form of illocutionary speech acts, the most dominant form is directif form. Second, the most dominant fuction of illocutionary speech acts is directif requestives fuction and directif requirements function. Third, the Putu Wijaya's Peace drama script dialogue fulllied three important aspects of teaching materials (1) language aspects; (2)psychology aspects; and (3) culture based aspects; and the curriculum that been used.
\end{abstract}

Keywords: drama script, dialogue of drama script, illocutionary speech acts, teaching materials, literatery education.

BASASTRA Jurnal Bahasa, Sastra, dan Pengajarannya

Volume 7 Nomor 1, April 2019, ISSN I2302-6405 


\section{PENDAHULUAN}

Keberadaan bahasa pada dasarnya tidak dapat dipisahkan dari kehidupan manusia, terutama dalam kehidupan bermasyarakat yang menuntut manusia tersebut berhubungan dan bekerja sama dengan sesamanya, sehingga untuk memenuhi hasratnya sebagai makhluk sosial yang perlu berinteraksi dengan orang lain, maka manusia memerlukan alat yang disebut bahasa. Bahasa memiliki peranan penting dalam kehidupan manusia, dengan bahasa manusia dapat menyampaikan berbagai gagasan, pikiran, dan perasaannya.

Konsep bahasa tentunya tidak dapat dipisahkan dengan komunikasi. Seseorang dapat berkomunikasi dengan orang lain menggunakan bahasa, baik bahasa tulis maupun bahasa lisan. Komunikasi bisa terjadi akibat interaksi dalam satu bentuk ujaran atau lebih yang melibatkan dua pihak, yaitu penutur dengan lawan tutur. Kelangsungan interaksi tersebut pada waktu, tempat, pokok tuturan, dan situasi tertentu dengan menggunakan bahasa sebagai alat komunikasinya. Komunikasi jelas bergantung bukan hanya pada kesadaran makna kata dalam ujarannya, tetapi juga mengetahui apa yang dimaksud oleh pembicara dengan ujarannya (Yule, 2015:187-188).

Suatu tuturan pasti mempunyai maksud serta faktor yang melatarbelakangi penutur dalam menyampaikan tuturannya kepada mitra tutur. Interaksi berupa tuturan dalam bentuk komunikasi dapat disebut sebagai tindak tutur. Pada kenyataannya, proses tindak tutur dapat dikatakan berhasil apabila penutur dan lawan tutur memahami maksud yang disampaikan atau menemukan kesepakatan akhir bersama terhadap tuturan yang disampaikan. Yule menjelaskan tindak tutur adalah suatu tindakan yang ditampilkan lewat tuturan (2006:82). Penutur tentunya berharap mitra tuturnya memahami maksud tuturannya.

Searle (dalam Rohmadi, 2010:20) mengemukakan bahwa secara pragmatis setidak-tidaknya ada tiga jenis tindakan yang dapat diwujudkan oleh seorang penutur, yakni tindak lokusi (locutionary act), tindak ilokusi (ilucotionary act), dan tindak perlokusi (perlocutionary act). Penelitian ini secara khusus meneliti tentang penggunaan tindak tutur ilokusi.

Tindak tutur terutama ilokusi dapat ditemukan pada berbagai ranah kehidupan manusia, salah satunya dapat ditemukan dalam karya sastra. Karya sastra merupakan karya seni yang menggunakan bahasa sebagai medianya, baik tulisan maupun lisan. Salah satu karya sastra yang menggunakan tindak tutur sebagai medianya adalah naskah drama. Tindak tutur dalam naskah drama terdapat pada dialog-dialog antar tokohnya dan disesuaikan dengan konteks atau situasi dan kondisi yang terjadi dalam setting naskah.

Drama merupakan mimetis dari kehidupan sehari-hari. Peristiwa yang terjadi di dalam naskah drama memiliki kesamaan dengan peristiwa dalam kehidupan sehari-hari. Waluyo (2003:6) mengungkapkan bahwa naskah drama disebut juga sastra lakon. Sebagai salah satu genre sastra, naskah drama dibangun oleh struktur fisik (kebahasaan) dan struktur batin (semantik, makna). Wujud fisik sebuah naskah drama adalah dialog atau ragam tutur.

Drama mengajarkan manusia akan problema kehidupan berupa moral, watak atau karakter, konflik, dan segala aspek kehidupan lainnya kepada manusia. Nilainilai ini tertuang tidak hanya pada amanatnya saja, tetapi juga terdapat di dalam dialog atau tuturan tokohnya. Dialog memiliki peran untuk menampakkan karakter dan memperkaya plot, menciptakan konflik, menghubungkan fakta-fakta, menghubungkan adeganadegan dan gambar-gambar sekaligus, menyamarkan kejadian-kejadian yang akan datang.

Salah satu penulis naskah drama terbaik di Indonesia adalah Putu Wijaya, Putu Wijaya merupakan sastrawan 
Indonesia yang telah banyak mempublikasikan berbagai karya sastra ciptaannya, salah satunya adalah karya sastra berupa naskah drama. Naskah dramanya yang terkenal antara lain adalah Dor, Peace, Edan, Bila Malam Bertambah Malam, Aduh, Dag-Dig-Dug, Peace, Anu, Hum Pim Pah, dan berbagai naskah drama lainnya. Putu Wijaya cenderung mengangkat tema kritik sosial dalam penulisan karya sastra terutama naskah dramanya. Berdasarkan hal tersebut penulis ingin mengetahui bagaimana dialog dalam naskah drama dapat dikaji dengan menggunakan konsep pragmatik terutama tuturan atau tindak tutur yang berkaitan dengan konteks (situasi dan kondisi).

Pemilihan naskah drama Peace karya Putu Wijaya sebagai objek penulisan dengan mempertimbangkan tema naskah yaitu kritik sosial terhadap masalah yang akhir-akhir ini marak diperbincangkan diseluruh dunia, perihal krisis perdamaian. Naskah drama Peace yang dipublikasikan pada tahun 2008 ini mengandung dialogdialog dengan makna tersirat maupun tersurat yang mendidik mengenai pesan perdamaian, selain itu dialognya penuh dengan kata-kata nasihat dan puitis. Konflik yang ditampilkan dalam naskah ini tidak begitu rumit, namun menimbulkan rasa keingin tahuan peneliti untuk mengupas lebih dalam mengenai pesan yang terkandung dan ingin disampaikan dalam setiap dialognya. Selain itu, naskah drama ini sarat akan nilai-nilai pendidikan karakter yang dikemas secara menarik dan menyenangkan.

Pada pembelajaran bahasa Indonesia di tingkat Sekolah Menengah Atas (SMA) khususnya mengenai naskah drama, diharuskan sesuai dengan Kompetensi Dasar (KD) 5.1 kelas XI SMA, yakni mengidentifikasi peristiwa, pelaku dan perwatakannya, dialog dan konflik pada drama, sehingga dalam hal ini peserta didik dilibatkan secara langsung untuk menulis naskah drama. Melalui pembelajaran ini, peserta didik dituntut untuk menulis naskah drama dengan menggunakan bahasa yang tepat untuk mendeskripsikan perilaku manusia, menghidupkan konflik dan peristiwa di dalam tuturan atau dialog tokoh.

Sedangkan pada praktiknya peserta didik dalam memahami dialog tokoh cenderung bersifat apa adanya atau secara langsung, yakni berdasarkan apa yang terdapat dalam tuturan tokoh saja padahal untuk memahami isi dialog tokoh perlu pengkajian secara mendalam.

Sesuai fungsi dialog di atas, penulis tertarik menggunakan naskah drama Peace karya Putu Wijaya. Melalui analisis dialog naskah drama ini, diharapkan siswa dapat lebih mudah memahami dan mengkaji perilaku tokoh berdasarkan tuturan atau dialognya.

Berlandaskan uraian di atas, maka penulis menganalisis tindak tutur ilokusi pada dialog-dialog naskah drama Peace karya Putu Wijaya. Penelitian ini mengambil judul "Analisis Tidak Tutur Ilokusi dalam Dialog Naskah Drama Peace Karya Putu Wijaya dan Relevansinya dengan Materi Ajar Sastra di Sekolah Menengah Atas". Peneliti melakukan penelitian dengan menggunakan pendekatan pragmatik tindak tutur.

\section{METODE PENELITIAN}

Penelitian ini berdasarkan bentuknya merupakan penelitian kualitatif, sedangkan berdasarkan tujuannya merupakan penelitian deskriptif dengan menggunakan pendekatan pragmatik. Penelitian deskriptif dapat diartikan sebagai prosedur pemecahan masalah yang diselidiki dengan menggambarkan atau melukiskan objek penelitian pada saat sekarang berdasarkan data/fakta-fakta yang tampak atau sebagaimana adanya.

Menurut Sukmadinata (2009:53-60), penelitian kualitatif adalah penelitian yang digunakan untuk mendeskripsikan dan menganalisis fenomena, peristiwa, aktivitas sosial, sikap, kepercayaan, presepsi, dan orang secara individual maupun kelompok. Sukmadinata 
(2009:18), menyatakan bahwa penelitian deskriptif bertujuan mendefinisikan suatu keadaan atau fenomena secara apa adanya. Berdasarkan uraian di atas dapat disimpulkan bahwa jenis penelitian ini menggunakan penelitian kualitatif karena analisis datanya berupa kata-kata tertulis atau lisan.

Data/fakta yang ada harus diolah dan ditafsirkan dengan menggunakan pendekatan pragmatik, sehingga dalam hal ini peneliti membuat deskripsi secara nyata dan faktual. Data/fakta tersebut juga harus diolah dan ditafsirkan dengan menggunakan pendekatan pragmatik yang berhubungan dengan konsep tindak tutur ilokusi dengan tujuan mendeskripsikan hasil penelitian secara sistematis mengenai tindak tutur ilokusi yang terjadi dalam dialog naskah drama Peace karya Putu Wijaya.

Penelitian ini tidak terikat tempat, karena untuk menjawab rumusan masalah tindak ilokusi dalam naskah drama, objek penelitian diambil hanya dari dialog-dialog pada naskah drama Peace karya Putu Wijaya. Namun untuk tambahan penelitian, diadakan wawancara dengan informan yaitu guru Bahasa Indonesia di SMAN 1 Surakarta. Waktu penelitian dilaksanakan pada bulan Agustus 2018 sampai dengan Januari 2019. Arikunto (1998:144) mengemukakan bahwa sumber data adalah subjek dari mana suatu data dapat diperoleh. Menurut Sutopo (2006:56-57), sumber data adalah tempat data diperoleh dengan menggunakan metode tertentu baik berupa manusia, artefak, ataupun dokumen-dokumen. Data dalam penelitian ini berupa tuturan atau dialog tokoh dalam naskah drama Peace karya Putu Wijaya, sedangkan sumber data dalam penelitian ini berupa dokumen. Dokumen tersebut bersumber dari naskah drama karya Putu Wijaya yang dipublikasikan di tahun 2008.

Teknik pengambilan penelitian ialah menggunakan teknik purposive sampling, yaitu teknik pengambilan sampel dengan tujuan tertentu. Menurut Arikunto (1998) pengertian purposive sampling adalah teknik mengambil sampel dengan tidak berdasarkan random, daerah atau strata, melainkan berdasarkan atas adanya pertimbangan yang berfokus pada tujuan tertentu. Purposive sampling lebih tepat digunakan oleh para peneliti apabila memang sebuah penelitian memerlukan kriteria khusus agar sampel yang diambil nantinya sesuai dengan tujuan penelitian dapat memecahkan permasalahan penelitian serta dapat memberikan nilai yang lebih representatif, sehingga teknik yang diambil dapat memenuhi tujuan sebenarnya dilakukannya penelitian.

Peneliti mengambil sampel berupa tuturan atau dialog tokoh dalam naskah drama karya Putu Wijaya. Adapun tujuan tersebut agar peneliti dapat melakukan penelitian dengan tepat. Tuturan atau dialog yang diteliti harus diiringi dengan konsep tindak tutur yang benar agar peneliti dapat menemukan dialog dengan aspek tindak tutur ilokusi.

Teknik pengumpulan data yang digunakan dalam penelitian kualitatif adalah teknik yang memungkinkan diperoleh data detail dengan waktu yang relatif lama. Menurut Sugiyono (2005:62), "Teknik pengumpulan data merupakan langkah yang paling strategis dalam penelitian, karena tujuan utama dari penelitian adalah mendapatkan data". Teknik pengumpulan data dalam penelitian ini menggunakan teknik observasi berupa analisis dokumen dan pencatatan. Menurut Nawawi dan Martini dalam Sugiyono (2005), observasi adalah pengamatan dan pencatatan secara sistematik terhadap unsur-unsur yang tampak dalam suatu gejala atau gejala-gejala pada objek penelitian.

Teknik analisis dokumen digunakan untuk menganalisis data tindak tutur ilokusi pada dialog naskah drama Peace karya Putu Wijaya. Peneliti menggunakan teknik analisis dokumen karena sumber data yang dianalisis berupa dokumen tertulis yaitu naskah drama Peace karya 
Putu Wijaya. Teknik pencatatan difungsikan untuk mencatat data-data atau temuan yang ada setelah mengamati objek yang dianalisis. Teknik ini meliputi pencatatan data yang dibutuhkan untuk dianalisis menggunakan teori yang ada. Peneliti mempersiapkan objek kajian, dalam hal ini berupa dialog pada naskah drama yang mengandung unsur tindak tutur ilokusi, kemudian setelah melakukan persiapan, peneliti melakukan pencatatan data dalam kartu data yang telah disiapkan.

Norman K. Denkin mendefinisikan triangulasi sebagai gabungan atau kombinasi berbagai metode yang dipakai untuk mengkaji fenomena yang saling terkait dari sudut pandang dan perspektif yang berbeda. Menurutnya, triangulasi meliputi empat hal, yaitu: (1) triangulasi metode, (2) triangulasi antar-peneliti (jika penelitian dilakukan dengan kelompok), (3) triangulasi sumber data, dan (4) triangulasi teori.

Triangulasi adalah cara yang paling umum digunakan dalam penjaminan validitas data dalam penelitian kualitatif. Peneliti menggunakan teknik triangulasi teori, yaitu teknik triangulasi yang dilakukan berdasarkan anggapan bahwa fakta tertentu tidak dapat diperiksa derajat kepercayaannya dengan satu teori saja, oleh karena itu penelitian ini akan mengumpulkan beberapa teori yang dikemukakan oleh beberapa ahli untuk mengambil data dialog yang bisa dikategorikan sebagai objek pragmatik berupa tindak tutur ilokusi.

Hasil akhir penelitian kualitatif berupa sebuah rumusan informasi atau thesis statement. Informasi tersebut selanjutnya dibandingkan dengan perspektif teori yang relevan untuk menghindari bias individual peneliti atas temuan atau kesimpulan yang dihasilkan. Selain itu, triangulasi teori dapat meningkatkan kedalaman pemahaman asalkan peneliti mampu menggali pengetahuan teoretik secara mendalam atas hasil analisis data yang telah diperoleh. Moleong (2004:280-281) mengemukakan analisis data adalah proses mengorganisasikan dan mengurutkan data kedalam pola, kategori, dan satuan uraian dasar sehingga dapat ditemukan tema dan tempat dirumuskan hipotesis kerja seperti yang disarankan oleh data.

Teknik analisis data yang digunakan dalam penelitian adalah model analisis mengalir atau flow model of analysis, proses analisis ini saling menjalin, dilakukan terus menerus dan berkesinambungan dalam proses pengumpulan data. Langkah-langkah analisis data menurut Miles dan Huberman (1992) adalah reduksi data, penyajian data atau display data, penarikan kesimpulan/verifikasi

\section{HASIL DAN PEMBAHASAN}

Naskah Drama Peace karya Putu Wijaya secara garis besar menceritakan tentang kedamaian hutan yang terusik karena ulah Pemburu Jahat yang ingin mencuri Telur Binatang Purba. Anak-anak Dunia dan Anak-Anak Raksasa berusaha membantu menyelamatkan Telur dari tangan Pemburu Jahat. Akan tetapi mereka harus melalui berbagai rintangan yang menguji ketahanan diri mereka dan keikhlasan diri mereka untuk terus membantu menyelamatkan Telur. Pemburu Jahat memanfaatkan motto hidup Anakanak Dunia dan Anak-Anak Raksasa yaitu membantu sesama yang lemah dan mengalami kesusahan, menjaga perdamaian, dan toleransi terhadap perbedaan. Pemburu Jahat pada konflik cerita berusaha memanfaatkan situasi tersebut agar Anak-anak Dunia dan AnakAnak Raksasa justru berbalik sikap untuk membantunya mencuri dan membawa Telur Binatang Purba.

Konflik penyelamatan Telur ini terus berlanjut sampai Telur menetas menjadi Anak Binatang Purba. Pemburu Jahat tetap mengejarnya dan hendak menjualnya untuk dipamerkan ke seluruh dunia dan nanti pada akhirnya Pemburu Jahat akan menjadi kaya raya. Akan tetapi 
berkat bantuan Anak-anak Dunia dan Anak-Anak Raksasa rencana dan usaha Pemburu Jahat berhasil digagalkan.

Menjelang akhir konflik, Anak-anak Dunia dan Anak Binatang Purba tertangkap dan disandera Pemburu Jahat. Namun berkat Anak-Anak Raksasa yang berhasil memberi kabar kepada Binatang Purba atau induk dari Anak Binatang Purba, penyanderaanpun berhasil di kacaukan. Binatang Purba muncul, Pemburu Jahat lari ketakutan dan pada akhirnya Anak Binatang Purba berhasil diselamatkan dan kembali dalam pelukan induknya. Anak-anak Dunia dan AnakAnak Raksasa bersama- sama dengan Anak Binatang Purba bersuka ria karena hutan kembali damai. Mereka menyerukan sorak dan lagu perdamaian.

Berdasarkan inti cerita diatas, peristiwa yang terjadi di dalam naskah secara tersirat juga terjadi pada kehidupan masa kini baik dalam kancah nasional maupun internasional. Isi dari naskah drama ini sesuai dengan keadaan dan situasi sosial baik di Indonesia maupun diseluruh dunia yang saat ini sedang darurat perdamaian.

\section{Bentuk Tindak Tutur Ilokusi dalam Dialog Naskah Drama Peace Karya Putu Wijaya}

Tindak tutur ilokusi adalah tindak tutur yang berfungsi menyatakan dan melakukan sesuatu. Dalam tindak tutur ini, satu tuturan mengandung dua maksud, yaitu menginformasikan dan menyuruh untuk melakukan sesuatu. Konteks dalam suatu tuturan sangat diperlukan untuk mengidentifikasi tindak tutur ini. Searle (1979: 12-17) mengklasifikasikan tindak ilokusi menjadi lima jenis, yaitu tindak tutur asertif, direktif, komisif, ekspresif, dan deklaratif.

Dalam dialog naskah drama Peace karya Putu Wijaya dari total 109 dialog terdapat 29 bentuk dialog asertif, 58 bentuk dialog direktif, 2 bentuk dialog komisif, 4 bentuk dialog ekpresif, dan 5 bentuk dialog deklaratif, dan 11 dialog tak bertindak tutur ilokusi. Berdasarkan bentuk dialognya, dialog tindak tutur ilokusi direktif adalah bentuk dialog tindak tutur ilokusi yang paling dominan yaitu sebanyak 58 dialog dan paling sering digunakan dalam naskah drama Peace karya Putu Wijaya.

Berikut akan dipaparkan masingmasing contoh tindak tutur ilokusi dan bentuk dialog tindak tutur ilokusi naskah drama Peace karya Putu Wijaya.

Tindak tutur asertif adalah tindak tutur yang mengikat penuturnya akan kebenaran atas apa yang diutarakan. Adapun yang termasuk dalam jenis tindak tutur ini adalah tuturan untuk menyatakan, memberitahukan, membanggakan, mengeluh, menuntut, dan melaporkan (Tarigan, 2009: 42-43).

Konteks: TERANG BULAN.
BINTANG-BINTANG BERKELAP-
KELIP MEMENUHI ANGKASA.
LAYAR PUTIH YANG
MEMENUHI SELURUH
PANGGUNG MULAI HIDUP.
BERGERAK-GERAK,
BERKERENYUT DIMAINKAN
DARI BELAKANG. ANGKASA
MENJADI RIMBA RAYA INDAH.
ANAK-ANAK RAKSASA GIMBAL
TERBANGUN DAN KELUAR
BERMAIN-MAIN DI DEPAN
LAYAR.

NYANYIAN RAKSASA GIMBAL Kita yang hidup di dalam hutan Pohon-pohon semua adalah teman Malam hari ada bintang dan bulan Margasatwa tidur kita mulai jumpalitan

Cari buah yang jatuh disenggol kelelawar

Sambil menyanyi menari kejarkejaran

Tidak seperti manusia yang suka tengkar

Mencuri milik orang tidak suka berkawan

(Dialog 1) 
Tindak tutur direktif adalah tindak tutur yang dimaksudkan penutur agar mitra tutur melakukan tindakan yang diinginkan oleh penutur. Berikut adalah contoh bentuk dialog tindak tutur ilokusi direktif yang terdapat dalam naskah drama Peace karya Putu Wijaya. Konteks: PEMBURU JAHAT
KEMUDIAN MEMAKAI TOPENG

PEMBURU JAHAT

Nah ini Mak sudah datang.

TELUR

Kenapa muka Mak jadi jelek?

\section{PEMBURU JAHAT}

Sebab pikiranmu yang bingung. Ini Mak tenanglah. Kamu capek. Oke, Mak gendong kamu bawa pulang. Mau?

\section{TELUR}

Mau.

(Dialog 15)

Tindak tutur komisif adalah tindak tutur yang mengikat penuturnya untuk melaksanakan apa yang disebutkan dalam tuturannya. Adapun yang termasuk dalam jenis tindak tutur ini adalah tuturan untuk menjanjikan, bersumpah, menawarkan, dan memanjatkan (doa) (Tarigan, 2009: 43). Berikut adalah contoh bentuk dialog tindak tutur ilokusi komisif yang terdapat dalam naskah drama Peace karya Putu Wijaya.

Konteks: TELUR MENYALA.

NAMPAK BAYANGAN ANAK BINATANG PURBA DI DALAM TELUR.

ANAK RAKSASA

Sttt dia mau tidur, jangan berisik. Yuk kita pulang sekarang

ANAK RAKSASA

Betul, bulan sudah jalan, kita mesti kembali, nanti kita dicari.
ANAK RAKSASA

Selamat malam telur.

ANAK RAKSASA

Sampai jumpa besok.

ANAK RAKSASA

Besok kita main bersama lagi.

(Dialog 7)

Tindak tutur ekspresif adalah tindak tutur yang mempunyai fungsi untuk mengekspresikan, mengungkapkan atau memberitahukan sikap psikologis penutur terhadap suatu keadaan yang tersirat dalam ilokusi. Adapun yang termasuk dalam jenis tindak tutur ini adalah tuturan untuk mengucapkan terima kasih, mengucapkan selamat, memaafkan, mengampuni, menyalahkan, memuji, menyatakan bela sungkawa, dan sebagainya (Leech dalam Tarigan, 2009: 43). Berikut adalah contoh bentuk dialog tindak tutur ilokusi ekspresif yang terdapat dalam naskah drama Peace karya Putu Wijaya.

Konteks: ANAK-ANAK RAKSASA MENOLAK DENGAN TANGAN.

\section{ANAK RAKSASA \\ Tidak!}

\section{PEMBURU JAHAT}

Ooooo, jadi ini kamu anak si Gimbal! Kamu yang sudah jahil mencuri telurku!

(Dialog 57)

Tindak tutur deklaratif adalah tindak tutur yang dimaksudkan penuturnya untuk menciptakan hal (status, keadaan, dan sebagainya) yang baru. Adapun yang termasuk dalam jenis tindak tutur ini adalah tuturan untuk menyerahkan diri, memecat, membebaskan, membaptis, memberi nama, menamai, mengucilkan, mengangkat, menunjuk, menentukan, menjatuhkan hukuman, menvonis, dan sebagainya (Tarigan, 2009: 44). Berikut adalah bentuk dialog tindak tutur ilokusi 
deklaratif yang terdapat dalam naskah drama Peace karya Putu Wijaya.

Konteks: PEMBURU JAHAT MENGELUARKAN TALINYA DAN SEPERTI KOBOI DIA MENJERAT SAPI. DI LAYAR NAMPAK BINTANG RAKSASA TERKENA JERAT.

PEMBURU JAHAT (Tertawa)

Aha dasar tolol

Badan besar

Kalau otak ompong

Pasti kalah

Aku akan kaya

Jadi selebriti

Aku akan kuasa

Masuk televisi

(Dialog 5)

Fungsi Tindak Tutur Ilokusi dalam Dialog Naskah Drama Peace Karya Putu Wijaya

Konteks dalam suatu tuturan sangat diperlukan untuk mengidentifikasi tindak tutur ini. Searle (1979: 12-17) mengklasifikasikan tindak ilokusi menjadi lima jenis, yaitu tindak tutur asertif, direktif, komisif, ekspresif, dan deklaratif. Berikut akan dipaparkan masing-masing tindak tutur ilokusi yang terdapat dalam naskah drama Peace karya Putu Wijaya. Naskah drama Peace karya Putu Wijaya memiliki 98 bentuk dialog ilokusi yang mempunyai fungsi sebagai berikut.

a. Dialog naskah drama Peace karya Putu Wijaya mengandung 29 dialog tindak tutur asertif yang memiliki fungsi tuturan untuk menyatakan, memberitahukan, membanggakan, mengeluh, menuntut, dan melaporkan.

b. Dialog naskah drama Peace karya Putu Wijaya mengandung 58 dialog tindak tutur direktif yang memiliki fungsi tuturan untuk requestives (meminta, mengemis, memohon, menekan, mengundang, mendoa, mengajak, mendorong), questions (bertanya, berinkuiri, menginterogasi), requirements (memerintah, menghendaki, mengkomando, menuntut, mendikte, mengarahkan, menginstruksikan, mengatur, mensyaratkan), prohibitive (melarang, membatasi), permissives (menyetujui, membolehkan, memberi wewenang, menganugrahi, mengabulkan, membiarkan, mengizinkan, melepaskan, memaafkan, memperkenankan), dan advisories (menasihatkan, memperingatkan, mengkonseling, mengusulkan, menyarankan, mendorong).

c. Dialog naskah drama Peace karya Putu Wijaya mengandung 2 dialog tindak tutur komisif yang memiliki fungsi tuturan untuk menjanjikan, bersumpah, menawarkan, dan memanjatkan (doa).

d. Dialog naskah drama Peace karya Putu Wijaya mengandung 4 dialog tindak tutur ekspresif yang memiliki fungsi tuturan untuk mengekspresikan, mengungkapkan atau memberitahukan sikap psikologis penutur terhadap suatu keadaan yaitu mengucapkan terima kasih, memaafkan, mengampuni, menyalahkan, memuji.

e. Dialog naskah drama Peace karya Putu Wijaya mengandung 5 dialog tindak tutur deklaratif yang memiliki fungsi tuturan untuk menciptakan hal (status, keadaan, dan sebagainya) yang baru yaitu menyerahkan diri, membebaskan, mengucilkan, menunjuk, menentukan, menjatuhkan hukuman, menvonis.

Berdasarkan fungsi dialog tindak tutur ilokusinya, fungsi tindak tutur ilokusi direktif merupakan fungsi yang paling dominan dan paling sering muncul dalam dialog naskah drama Peace karya Putu Wijaya. Fungsi requestives dan requirements merupakan fungsi yang paling sering digunakan pada dialog naskah drama ini.

Berikut akan dipaparkan masingmasing contoh tindak tutur ilokusi dan bentuk dialog tindak tutur ilokusi naskah drama Peace karya Putu Wijaya.

Tindak tutur asertif adalah tindak tutur yang mengikat penuturnya akan kebenaran atas apa yang diutarakan. Adapun yang termasuk dalam jenis tindak 
tutur ini adalah tuturan untuk menyatakan, memberitahukan, membanggakan, mengeluh, menuntut, dan melaporkan (Tarigan, 2009: 42-43).

Konteks: TERANG BULAN.
BINTANG-BINTANG BERKELAP-
KELIP MEMENUHI ANGKASA.
LAYAR PUTIH YANG
MEMENUHI SELURUH
PANGGUNG MULAI HIDUP.
BERGERAK-GERAK,
BERKERENYUT DIMAINKAN
DARI BELAKANG. ANGKASA
MENJADI RIMBA RAYA INDAH.
ANAK-ANAK RAKSASA GIMBAL
TERBANGUN DAN KELUAR
BERMAIN-MAIN DI DEPAN
LAYAR.

NYANYIAN RAKSASA GIMBAL

Kita yang hidup di dalam hutan Pohon-pohon semua adalah teman Malam hari ada bintang dan bulan Margasatwa tidur kita mulai jumpalitan

Cari buah yang jatuh disenggol kelelawar

Sambil menyanyi menari kejarkejaran

Tidak seperti manusia yang suka tengkar

Mencuri milik orang tidak suka berkawan

(Dialog 1)

Tuturan tersebut merupakan tindak tutur ilokusi asertif yang berfungsi menyatakan dan membanggakan diri. Hal tersebut dapat diketahui dari nyanyian Raksasa Gimbal yang mengungkapkan kehidupan makhluk di dalam hutan, selain itu Raksasa Gimbal membanggakan kehidupan makhluk hutan yang hidup dalam kedamaian tidak seperti manusia yang suka bertengkar dan mencuri milik sesamanya.

Tindak tutur direktif adalah tindak tutur yang dimaksudkan penutur agar mitra tutur melakukan tindakan yang diinginkan oleh penutur. Berikut adalah contoh bentuk dialog tindak tutur ilokusi direktif yang terdapat dalam naskah drama Peace karya Putu Wijaya.

Konteks: PEMBURU JAHAT
KEMUDIAN MEMAKAI TOPENG

PEMBURU JAHAT

Nah ini Mak sudah datang.

TELUR

Kenapa muka Mak jadi jelek?

\section{PEMBURU JAHAT}

Sebab pikiranmu yang bingung. Ini Mak tenanglah. Kamu capek. Oke, Mak gendong kamu bawa pulang. Mau?

\section{TELUR}

Mau.

(Dialog 15)

Tuturan tersebut merupakan tindak tutur ilokusi direktif questions dan requirements yang berfungsi menginterogasi dan mengarahkan. Hal tersebut dapat diketahui dari tuturan Telur yang ragu-ragu dan menanyakan alasan perubahan bentuk fisik wajah induknya yang menjadi jelek. Selain itu, Pemburu Jahat menyamar dan mengelabui Telur dengan cara meyakinkan Telur menggunakan berbagai alasan agar Telur menyetujui tuturannya.

Tindak tutur komisif adalah tindak tutur yang mengikat penuturnya untuk melaksanakan apa yang disebutkan dalam tuturannya. Adapun yang termasuk dalam jenis tindak tutur ini adalah tuturan untuk menjanjikan, bersumpah, menawarkan, dan memanjatkan (doa) (Tarigan, 2009: 43). Berikut adalah contoh bentuk dialog tindak tutur ilokusi komisif yang terdapat dalam naskah drama Peace karya Putu Wijaya.

Konteks: TELUR MENYALA.

NAMPAK BAYANGAN ANAK BINATANG PURBA DI DALAM TELUR.

ANAK RAKSASA 
Stttt dia mau tidur, jangan berisik. Yuk kita pulang sekarang

ANAK RAKSASA

Betul, bulan sudah jalan, kita mesti kembali, nanti kita dicari.

ANAK RAKSASA

Selamat malam telur.

ANAK RAKSASA

Sampai jumpa besok.

ANAK RAKSASA

Besok kita main bersama lagi.

(Dialog 7)

Tuturan tersebut merupakan tindak tutur ilokusi komisif yang berfungsi menjanjikan sesuatu. Hal tersebut dapat diketahui dari tuturan Anak Raksasa kepada Telur agar Telur beristirahat karena hari sudah malam dan Anak Raksasa menjanjikan besok akan bermain bersama dengan Telur kembali jika Telur mau menuruti perkataan Anak Raksasa.

Tindak tutur ekspresif adalah tindak tutur yang mempunyai fungsi untuk mengekspresikan, mengungkapkan atau memberitahukan sikap psikologis penutur terhadap suatu keadaan yang tersirat dalam ilokusi. Adapun yang termasuk dalam jenis tindak tutur ini adalah tuturan untuk mengucapkan terima kasih, mengucapkan selamat, memaafkan, mengampuni, menyalahkan, memuji, menyatakan bela sungkawa, dan sebagainya (Leech dalam Tarigan, 2009: 43). Berikut adalah contoh bentuk dialog tindak tutur ilokusi ekspresif yang terdapat dalam naskah drama Peace karya Putu Wijaya.

Konteks: ANAK-ANAK RAKSASA MENOLAK DENGAN TANGAN.

ANAK RAKSASA

Tidak!

PEMBURU JAHAT
Ooooo, jadi ini kamu anak si Gimbal! Kamu yang sudah jahil mencuri telurku!

(Dialog 57)

Tuturan tersebut merupakan tindak tutur ilokusi ekspresif yang berfungsi menyalahkan dan menyepelekan. Hal tersebut dapat diketahui dari tuturan Pemburu Jahat yang menyalahkan dan menyepelekan Anak Raksasa yang mengambil Telur. Tuturan tersebut mengekspresikan kekesalan Pemburu Jahat.

Tindak tutur deklaratif adalah tindak tutur yang dimaksudkan penuturnya untuk menciptakan hal (status, keadaan, dan sebagainya) yang baru. Adapun yang termasuk dalam jenis tindak tutur ini adalah tuturan untuk menyerahkan diri, memecat, membebaskan, membaptis, memberi nama, menamai, mengucilkan, mengangkat, menunjuk, menentukan, menjatuhkan hukuman, menvonis, dan sebagainya (Tarigan, 2009: 44). Berikut adalah bentuk dialog tindak tutur ilokusi deklaratif yang terdapat dalam naskah drama Peace karya Putu Wijaya.

Konteks: PEMBURU JAHAT MENGELUARKAN TALINYA DAN SEPERTI KOBOI DIA MENJERAT SAPI. DI LAYAR NAMPAK BINTANG RAKSASA TERKENA JERAT.

PEMBURU JAHAT (Tertawa)

Aha dasar tolol

Badan besar

Kalau otak ompong

Pasti kalah

Aku akan kaya

Jadi selebriti

Aku akan kuasa

Masuk televisi

(Dialog 5)

Tuturan tersebut merupakan tindak tutur ilokusi deklaratif yang berfungsi menginginkan dan mengharapkan sesuatu. 
Hal tersebut dapat diketahui dari tuturan Pemburu Jahat yang mengungkapkan keinginan dan harapannya untuk hidup kaya raya, terkenal, dan berkuasa. Pemburu Jahat ingin menciptakan status dan keadaan yang baru dengan menangkap Binatang Raksasa.

Relevansi Dialog Naskah Drama Peace Karya Putu Wijaya dengan Materi Ajar Sastra di Sekolah Menengah Atas

Materi ajar adalah seperangkat materi pembelajaran yang mengacu pada kurikulum yang digunakan (dalam hal ini adalah silabus mata pelajaran) dalam rangka mencapai standar kompetensi dan kompetensi dasar yang telah ditentukan (Lestari, 2013:2). Dalam menyusun sebuah materi ajar harus berpedoman pada kurikulum yang berlaku, sehingga materi ajar tersebut dapat digunakan untuk mencapai kompetensi inti dan kompetensi dasar. Rahmanto (1988:27) menjelaskan bahwa pemilihan materi pengajaran sastra juga harus mempertimbangkan tiga aspek penting, yaitu segi bahasa, segi kematangan jiwa (psikologi), dan sudut latar belakang kebudayaan.

Berdasarkan penelitian yang telah dilakukan terhadap naskah drama Peace karya Putu Wijaya, ketiga aspek tersebut dapat ditemukan dalam naskah ini.

Pertama, yaitu dari segi bahasa, naskah drama Peace karya Putu Wijaya memenuhi aspek tersebut. Naskah drama Peace karya Putu Wijaya jika ditinjau dari segi bahasanya sangat menarik. Dialog yang digunakan dalam naskah drama ini mengandung banyak tindak tutur bahasa yang memungkinkan pembaca memahami maksud dialog dan keinginan hati setiap tokohnya.

Selain itu, Ibu Dra. Endah Sri, M.Pd menyampaikan pada wawancaranya dengan penulis sebagai berikut.

"Bahasa yang digunakan pengarang mampu meningkatkan imajinasi pembacanya.

Penggunaan diksi yang variatif dapat menambah wawasan peserta didik. Dialognya sederhana dan tidak bertele-tele, serta memasukan unsur dialog percakapan masa kini yang tidak asing bagi pembaca seusia peserta didik."

(CLHW-EN-3)

Penggunan bahasa sehari-hari
membuat hampir semua kalangan
khususnya peserta didik memahami naskah
drama ini dengan cukup mudah. Seperti
yang disampaikan Ibu Dian, S.Pd yaitu,
"Ada beberapa penggunaan
bahasa asing, bahasa daerah, dan
bahasa sehari-hari yang sifatnya
nonbaku, namun hal tersebut tidak
mengubah pesan dialog, dan
justru membuat dialog menjadi
tidak kaku dan lebih hidup ketika
nantinya dipentaskan. Pemilihan
kata-kata yang digunakan juga
wajar apabila digunakan sebagai
materi ajar di SMA."

(CLHW-DN-3)

Berdasarkan pendapat kedua guru diatas, penulis mengintepretasikan bahwa naskah drama Peace karya Putu Wijaya jika ditinjau dari segi bahasanya telah memenuhi aspek kebahasaan sebagai materi ajar sastra. Penggunaan diksinya bervariasi dan dapat menambah wawasan peserta didik. Dialognya sederhana dan tidak bertele-tele, serta memasukan unsur dialog percakapan masa kini yang tidak asing bagi pembaca seusia peserta didik. Dialognya tidak kaku dan lebih hidup ketika nantinya dipentaskan. Pemilihan kata-kata yang digunakan juga wajar apabila digunakan sebagai materi ajar di SMA.

Kedua, berdasarkan aspek kematangan jiwa (psikologis), cerita yang disajikan pengarang secara tersirat merupakan gambaran mengenai kehidupan yang saat ini. Ibu Dra. Endah Sri, M.Pd menyampaikan pendapatnya sebagai berikut. 
"Naskah drama ini sebenarnya mengangkat tema yang serius yaitu tentang perdamaian dunia namun dikemas secara menarik, tidak berlebihan, dan menyenangkan."

\section{(CLHW-EN-1)}

Selaras dengan pendapat Ibu Dra. Endah Sri, M.Pd, Ibu Dian, S.Pd menyampaikan pendapatnya sebagai berikut.

"Sehingga dapat dikatakan pesan atau amanat yang disampaikan baik, mengandung nilai pendidikan karakter khususnya cinta damai dan toleransi, bahasa dan isi naskah juga sesuai dengan karakteristik peserta didik ditingkat SMA."

(CLHW-DN-6)

Sehingga dapat disimpulkan bahwa naskah drama Peace karya Putu Wijaya ini mengangkat tema dan memiliki amanat yang baik, dikemas secara menarik, tidak berlebihan, dan menyenangkan. Selain itu, naskah mengandung nilai pendidikan karakter khususnya cinta damai dan toleransi, bahasa dan isi naskah juga sesuai dengan karakteristik peserta didik khususnya aspek usia dan kematangan jiwa di tingkat SMA sehingga cocok jika digunakan sebagai materi ajar di SMA.

Ketiga, berdasarkan latar belakang budaya peserta didik, peristiwa di dalam naskah secara tersirat juga terjadi pada kehidupan masa kini baik dalam kancah nasional maupun internasional. Isi dari naskah drama ini sesuai dengan keadaan dan situasi sosial baik di Indonesia maupun diseluruh dunia yang saat ini sedang darurat perdamaian. Hal ini berarti kejadian dalam cerita juga terjadi di lingkungan sosial peserta didik. Zaman sekarang ini tak jarang peserta didik juga bersinggungan dengan hal-hal yang berhubungan dengan perdamaian dan pertikaian.
"Penggambaran tokoh, sifat tokoh, dan dialog-dialognya sanagt mencerminkan nilai-nilai pendidikan karakter yang berguna bagi peserta didik untuk menghadapi kehidupan bersosialnya di masa kini. Misalnya tokoh Anak Dunia dan Anak Raksasa yang saling membantu untuk menyelamatkan Telur tanpa memandang perbedaan mengandung nilai pendidikan karakter toleransi dan peduli sosial. Tokoh Anak Dunia yang menjunjung tinggi perdamaian dan kesejahteraan hutan menggambarkan nilai pendidikan cinta damai, dan lain sebagainya, singkatnya menurut saya banyak amana baik yang dapat diambil dari naskah drama ini dan mengandung nilai pendidikan karakter."

(CLHW-DN-4)

Dapat dikatakan bahwa melalui penggambaran cerita, dialog, dan tokohtokohnya, naskah drama ini mengajarkan pada peserta didik untuk memiliki pandangan lain terhadap suatu masalah, yaitu untuk menyikapi segala hal dengan bijaksana, saling tolong-menolong antar makhluk hidup, dan menjaga perdamaian.

Pada kurikulum 2013 mata pelajaran bahasa Indonesia di SMA kelas XI terdapat kompetensi dasar yang menuntut peserta didik untuk mampu mengidentifikasi peristiwa, pelaku dan perwatakannya, dialog dan konflik pada drama, sehingga dalam tujuan pembelajarannya peserta didik mampu dilibatkan secara langsung untuk menulis naskah drama sendiri. Jadi pemilihan materi ajar juga harus disesuaikan dengan kurikulum yang berlaku.

Analisis tindak tutur ilokusi dalam naskah drama juga relevan digunakan sebagai materi ajar. Dengan menganalisis tindak tutur dialog naskah drama, peserta didik dapat lebih mudah mengetahui 
struktur naskah drama, karakteristik dialog naskah drama, dan pada akhirnya dapat membuat naskah drama sendiri sehingga sesuai dengan kompetensi dasar dan tujuan pembelajaran. Selain itu, pendidik juga dituntut untuk mampu menghadirkan materi ajar yang menarik minat peserta didik.

Naskah drama Peace relevan dijadikan sebagai materi ajar di SMA terutama kelas XI karena cerita di dalamnya memuat peristiwa yang menarik dan bermanfaat bagi peserta didik. Nilai pendidikan karakter dengan pengajaran sastra Indonesia di SMA selalu berkaitan erat. Pendidikan karakter dipastikan memiliki relevansi dengan pembelajaran di sekolah. Sehingga dengan menggunakan naskah drama ini secara tidak langsung pembaca atau peserta didik dapat meneladani cara pembentukan karakter tokoh-tokohnya tersebut. Naskah drama ini membuat peserta didik sebagai pembacanya menyadari betapa pentingnya menjaga perdamaian dunia, tolong menolong, dan sikap toleransi antar umat manusia tanpa memandang perbedaan.

Hal inilah yang menjadi salah satu kelebihan dari naskah drama Peace karya Putu Wijaya bahwa naskah ini bukan hanya menjadi naskah yang cocok untuk kehidupan sosial bermasyarakat masa kini, tetapi juga merupakan naskah yang penuh dengan nilai pendidikan karakter, kelebihan dari naskah ini belum tentu dimiliki oleh naskah lain. Dengan nilai pendidikan karakter yang dapat diambil dari naskah drama Peace karya Putu Wijaya, naskah ini patut dijadikan sebagai alternatif materi pembelajaran sastra di SMA.

\section{Implikasi dengan Masalah Pendidikan Khususnya dalam Pengajaran Bahasa Indonesia}

Karya sastra yang hadir saat ini dapat dijadikan sebagai bagian dari pendidikan. Hal tersebut terjadi karena karya sastra yang dihasilkan oleh para penulis memiliki nilai pendidikan karakter yang ditanamkan pada diri pembaca. Nilai pendidikan karakter digambarkan melalui karakter-karakter tokoh dalam cerita yang dibuat sehidup mungkin oleh penulis.

Naskah drama Peace karya Putu Wijaya adalah salah satu karya sastra yang bermutu dan memiliki nilai pendidikan karakter yang baik untuk dijadikan materi ajar dalam proses pembelajaran bahasa Indonesia. Hasil penelitian ini mempunyai implikasi dengan dunia pendidikan khususnya dalam pengajaran sastra.

Penelitian ini mempunyai implikasi dengan masalah pendidikan khususnya dalam pengajaran bahasa Indonesia. Pembelajaran Bahasa Indonesia seringkali berhadapan dengan sebuah karya sastra. Sebuah karya sastra dapat memberikan pelajaran dari isi cerita yang dibuat penulis untuk menjadi contoh yang baik dalam kehidupan.

Secara teoretis, penelitian ini berimplikasi pada pengembangan wawasan dan memperkaya khazanah keilmuan tentang apresiasi sastra dengan menggunakan

pendekatan psikologi sastra. Penelitian ini memuat teori-teori tentang sastra dari beberapa ahli sehingga dapat digunakan sebagai materi referensi. Jadi, bagi peneliti lain yang akan melakukan penelitian serupa, dapat menggunakan penelitian ini sebagai acuannya.

Implikasi pedagogis, yaitu penelitian ini dapat menambah referensi naskah drama yang digunakan dalam pembelajaran sastra yang terdapat dalam mata pelajaran bahasa Indonesia pada tingkat SMA, terutama untuk kelas XI. Naskah drama Peace karya Putu Wijaya mempunyai isi yang mudah dipahami, sehingga dapat digunakan sebagai materi pembelajaran bahasa dan sastra yang tentunya saling berkaitan. Nilai-nilai pendidikan karakter yang terkandung dalam naskah drama Peace karya Putu Wijaya dapat memberikan gambaran positif yang mendidik. Melalui bacaan seperti ini peserta didik diharapkan dapat memetik pelajaran dan mengambil hikmah 
dari peristiwa-peristiwa yang diceritakan dalam naskah drama untuk menjadi pembelajaran dan pedoman hidup dalam menjalani kehidupan sehari-hari.

Pemaparan nilai-nilai pendidikan dalam karya sastra sangat perlu untuk diketahui dan dipelajari para peserta didik. naskah drama Peace karya Putu Wijaya mengandung nilai-nilai pendidikan karakter yang baik dan dapat dijadikan teladan bagi kehidupan sehari-hari.

Selain beberapa hal yang telah disebutkan, naskah drama Peace karya Putu Wijaya juga menunjukkan informasi faktual tentang kehidupan dan gambaran tentang perdamaian yang terusik karena adanya pertikaian. Peserta didik diharapkan dapat meneladani karakter positif dari para tokoh dan mengambil hikmah cerita dari dalam naskah drama tersebut. Cerita tentang perdamaian hutan yang terusik oleh Pemburu Jahat dan penyelamatan heroik dan sikap tolongmenolong dari berbagai makhluk hidup tanpa memandang perbedaan yang diangkat dalam naskah ini dapat menginspirasi dan memotivasi peserta didik untuk selalu memiliki pandangan lain terhadap suatu masalah, yaitu menyikapi segala hal dengan bijaksana, saling tolongmenolong antar makhluk hidup, toleransi terhadap perbedaan, dan menjaga perdamaian.

Secara praktis, implikasi dari penelitian ini adalah pengembangan kajian pragmatik tindak tutur. Dalam dunia pendidikan kajian ini menjadikan peserta didik mampu mengetahui, mengenal, dan menganalisis bentuk dan fungsi tindak tutur dalam dialog yang terdapat dalam naskah drama untuk dikaitkan secara kontekstual dengan kehidupan sehari-hari. Penelitian ini dapat dijadikan sebagai salah satu contoh dalam analisis karya sastra sehingga peneliti lain termotivasi untuk melakukan penelitian yang nantinya dapat diaplikasikan dalam pembelajaran sastra.

Hasil penelitian ini juga diharapkan dapat berperan dalam menumbuhkan minat dan sikap peserta didik untuk dapat mengapresiasi suatu karya sastra. Selain itu, penelitian ini juga diharapkan mampu memotivasi serta menumbuhkan minat membaca peserta didik terhadap sastra. Namun, selain berisi nilai-nilai positif, dalam naskah drama Peace karya Putu Wijaya juga terdapat unsur-unsur yang bersifat negatif.

Untuk itu pembaca hendaknya mampu memilah nilai-nilai baik yang dapat diteladani dalam naskah drama ini dan mawas diri terhadap hal-hal yang tidak baik dan tidak layak untuk diterapkan dalam kehidupan nyata.

\section{SIMPULAN}

Berdasarkan hasil analisis dan pembahasan terhadap dialog naskah drama Peace karya Putu Wijaya serta relevansinya dengan materi ajar sastra di SMA dalam penelitian ini dapat disimpulkan sebagai berikut:

Pertama, tindak ilokusi adalah tindak tutur yang selain berfungsi untuk mengatakan atau menginformasikan sesuatu, tetapi juga dipergunakan untuk melakukan sesuatu. Tindak tutur ini sangat sulit untuk diidentifikasi karena terlebih dahulu harus mempertimbangkan siapa penutur dan lawan tuturnya. Tindak ilokusi sering disebut sebagai the act of doing something (Rohmadi, 2010: 33). Tindak ilokusi menjadi lima jenis, yaitu tindak tutur asertif, direktif, komisif, ekspresif, dan deklaratif. Dalam dialog naskah drama Peace karya Putu Wijaya dari total 109 dialog terdapat 29 bentuk dialog asertif, 58 bentuk dialog direktif, 2 bentuk dialog komisif, 4 bentuk dialog ekpresif, dan 5 bentuk dialog deklaratif, dan 11 dialog tak bertindak tutur ilokusi. Berdasarkan bentuk dialognya, dialog tindak tutur ilokusi direktif adalah bentuk dialog tindak tutur ilokusi yang paling dominan yaitu sebanyak 58 dialog dan paling sering digunakan dalam naskah drama Peace karya Putu Wijaya.

Kedua, tindak tutur ilokusi adalah tindak tutur yang berfungsi menyatakan dan melakukan sesuatu. Dalam tindak tutur 
ini, satu tuturan mengandung dua maksud, yaitu menginformasikan dan menyuruh untuk melakukan sesuatu. Konteks dalam suatu tuturan sangat diperlukan untuk mengidentifikasi tindak tutur ini. Searle (1979: 12-17) mengklasifikasikan tindak ilokusi menjadi lima jenis, yaitu tindak tutur asertif, direktif, komisif, ekspresif, dan deklaratif. Berikut akan dipaparkan masing-masing tindak tutur ilokusi yang terdapat dalam naskah drama Peace karya Putu Wijaya. Naskah drama Peace karya Putu Wijaya memiliki 98 bentuk dialog ilokusi yang mempunyai fungsi sebagai berikut.

Pertama, dialog naskah drama Peace karya Putu Wijaya mengandung 29 dialog tindak tutur asertif yang memiliki fungsi tuturan untuk menyatakan, memberitahukan, membanggakan, mengeluh, menuntut, dan melaporkan.

Kedua, dialog naskah drama Peace karya Putu Wijaya mengandung 58 dialog tindak tutur direktif yang memiliki fungsi tuturan untuk requestives (meminta, mengemis, memohon, menekan, mengundang, mendoa, mengajak, mendorong), questions (bertanya, berinkuiri, menginterogasi), requirements (memerintah, menghendaki, mengkomando, menuntut, mendikte, mengarahkan, menginstruksikan, mengatur, mensyaratkan), prohibitive (melarang, membatasi), permissives (menyetujui, membolehkan, memberi wewenang, menganugrahi, mengabulkan, membiarkan, mengizinkan, melepaskan, memaafkan, memperkenankan), dan advisories memperingatkan, (menasihatkan, mengusulkan, menyarankan, mendorong).

Ketiga, dialog naskah drama Peace karya Putu Wijaya mengandung 2 dialog tindak tutur komisif yang memiliki fungsi tuturan untuk menjanjikan, bersumpah, menawarkan, dan memanjatkan (doa).
Keempat, dialog naskah drama Peace karya Putu Wijaya mengandung 4 dialog tindak tutur ekspresif yang memiliki fungsi tuturan untuk mengekspresikan, mengungkapkan atau memberitahukan sikap psikologis penutur terhadap suatu keadaan yaitu mengucapkan terima kasih, memaafkan, mengampuni, menyalahkan, memuji.

Kelima, dialog naskah drama Peace karya Putu Wijaya mengandung 5 dialog tindak tutur deklaratif yang memiliki fungsi tuturan untuk menciptakan hal (status, keadaan, dan sebagainya) yang baru yaitu menyerahkan diri, membebaskan, mengucilkan, menunjuk, menentukan, menjatuhkan hukuman, menvonis.

Berdasarkan fungsi dialog tindak tutur ilokusinya, fungsi tindak tutur ilokusi direktif merupakan fungsi yang paling dominan dan paling sering muncul dalam dialog naskah drama Peace karya Putu Wijaya. Fungsi requestives dan requirements merupakan fungsi yang paling sering digunakan pada dialog naskah drama ini.

Berdasarkan data dari hasil analisis dan wawancara dari para informan mengenai materi pembelajaran Bahasa Indonesia dan teori yang disampaikan oleh Rahmanto terkait relevansinya sebagai materi ajar sastra, naskah drama Peace karya Putu Wijaya telah memenuhi tiga aspek penting, yaitu segi bahasa, segi kematangan jiwa (psikologi), dan sudut latar belakang kebudayaan. Maka dapat disimpulkan bahwa naskah drama Peace karya Putu Wijaya mempunyai nilai pendidikan karakter yang baik dan bisa digunakan sebagai alternatif dalam pembelajaran sastra Indonesia di SMA khususnya kelas XI. Kesesuaian ini berdasarkan kompetensi inti dan kompetensi dasar yang tercantum dalam kurikulum 2013 serta kesesuaiannya dengan tingkat kemampuan peserta didik. 


\section{REFERENSI}

Arikunto, Si. (1998). Prosedur Penelitian Suatu Pendekatan Praktik. Jakarta: PT. Rineka Cipta.

Herfanda. (2008). "Sastra sebagai Agen Perubahan Budaya" dalam Bahasa dan Budya dalam Berbagai Prespektif, Aanwar Effendi, ed. Yogyakarta: FBS UNY dan Tiara Wacana.

Ibrahim. (1993). Kajian Tindak Tutur. Surabaya: Usaha Nasional Luwarsih.

Ismawati. (2013). Pengajaran Sastra. Yogyakarta: Ombak.

Kurniawan. (2008). "Analisis Tindak Tutur pada Dialog Non-Cerita Gie karya Sutradara Riri Reza". Skripsi. Surakarta. UNS.

Lestari. (2013). Pengembangan Bahan Ajar Berbasis Kompetensi. Padang: Akademia Permata.

Moloeng. (2001). Metodologi Penelitian Kualitatif. Bandung: Remaja Rosdakarya.

Rahardi. (2005). Pragmatik Kesantunan Imperatif Bahasa Indonesia. Jakarta: Erlangga.

Rahmanto. (1998). Metode Pengajaran Sastra. Yogyakarta: Kanisius.

Rohmadi. (2010). Pragmatik: Teori dan Analisis. Surakarta: Yuma Pustaka.

Satoto. (2012). Analisis Drama dan Teater. Yogyakarta: Ombak.

Sukmadinata. (2009). Metode Pendekatan Pendidikan. Bandung: PT Remaja Rosdakarya Offset.

Sugiono. (2005). Statistika untuk Penelitian. Jakarta: Alvabeta.

Sutopo. (2014). Metodologi Penelitian Kualitatif, Dasar Teori dan Penerapannya dalam Penelitian. Surakarta: Sebelas Maret University Press.

Tarigan. (2009). Pengajaran Pragmatik. Bandung: Penerbit Angkasa.

Waluyo. (2003). Drama: Teori dan Pengajarannya. Yogyakarta: Hanindita Graha Widya.
Wardani. (2009). Makna Totalitas dalam Karya Sastra. Surakarta: UNS Press.

Wibowo. (2013). Pendidikan Karakter Strategi Membangun Karakter Bangsa Berperadaban. Yogyakarta: Pustaka Pelajar.

Wijana, M. (2009). Analisis Wacana Pragmatik: Kajian Teori dan Analisis. Surakarta: Yuma Pustaka.

Yule. (2015). Kajian Bahasa: Edisi Lima. Yogyakarta: Pustaka Pelajar. 